\title{
ここまで分かった亜鉛の免疫システムにおける役割
}

\author{
西田圭吾 \\ 独立行政法人理化学研究所 統合生命医科学研究センター 恒常性ネットワーク研究チーム
}

\section{New Knowledge from Past Decade: Role of Zinc in Immune System}

\author{
Keigo NISHIDA \\ Laboratory for Homeostatic Network, RIKEN Center for Integrative Medial Sciences (IMS-RCAI)
}

\begin{abstract}
Zinc ( $\mathrm{Zn}$ ) is essential for normal cell structure and physiology. Its deficiency causes growth retardation, neuronal degeneration, and immunodeficiency. $\mathrm{Zn}$ homeostasis is tightly controlled through $\mathrm{Zn}$ transporters and metallothioneins, which regulate $\mathrm{Zn}$ concentration and $\mathrm{Zn}$ distribution in individual cells, and contributes to $\mathrm{Zn}$-binding protein in cells. Although many molecules involved in these processes have $\mathrm{Zn}$-binding motifs, the molecular mechanisms underlying the role of $\mathrm{Zn}$ in the immune system have not been clarified. Recently, we and other groups have demonstrated that $\mathrm{Zn}$ plays diverse and specific roles in vivo and in vitro, in studies on the genetic knockout of $\mathrm{Zn}$ transporter functions. In this review, we discuss the impact of $\mathrm{Zn}$ on mast cell-mediated allergy and $\mathrm{T}$ cell-mediated immune responses. We also describe $\mathrm{Zn}$ dysregulation as a leading health problem in allergy and immune responses.
\end{abstract}

Key words： zinc（亜鉛），immunity（免疫）, mast cell（マスト細胞），T cell（T細胞）, dendritic cell (樹状細胞), allergy（アレルギー）, autoimmune disease（自己免疫疾患）

\section{1. はじめに}

亜鉛は微量必須元素の一つであり，亜鉛欠乏により， 免疫系, 神経系, 内分泌系の異常を呈することが報告さ れている。これら亜鉛欠乏によって生じる様々な疾患は 200 種以上の酵素がその活性化に亜鉛を必要とされてい ることや，亜鉛フィンガーを有した多くの亜鉛結合性の 転写因子やシグナル伝達分子が存在し, これら亜鉛要求 性の蛋白質構造になんらかの異常をもたらすためではな いかと考えられている。

一方, 免疫システムはヒトが通常に生活していくう光 で必須な生体恒常性システムであり, 様々な免疫担当細 胞や免疫関連分子が複雑に相互作用することにより成り 立っている。また，その破綻は自己免疫疾患・感染症・

受付 2013 年 5 月 31 日, 受理 2013 年 7 月 29 日

Reprint requests to: Keigo NISHIDA

Laboratory for Homeostatic Network, RIKEN Center for Integrative Medial Sciences (IMS-RCAI), Yokohama, Kanagawa 230-0045, Japan TEL: +81(45)503-7075, FAX: +81(45)503-9688

E-mail: nishida@rcai.riken.jp
アレルギー疾患などの免疫関連疾患を引き起こす。

先に述べたように，亜鉛欠乏により，多彩な病態が観 察されるが，神経系や内分泌系と亜鉛に関する研究が先 行して推進されてきた歴史があり，免疫系と亜鉛に関す る研究は現象論の域を超えないままであった。しかし， 最近の日本及び海外の免疫学者の研究の参画により, 亜 鉛欠乏による免疫異常も細胞・分子レベルで説明できる よらになりつつある。

本稿では，あきらかになりつつある亜鉛と免疫担当細 胞機能発現，特に，樹状細胞，マスト細胞， $\mathrm{T}$ 細胞に関 する分子レベルでの知見，さらにはこれらの細胞が関与 している免疫関連疾患に関して，亜鉛がどのよらな役割 を担っているかについて最新の研究成果を踏まえて紹介 したい。

\section{2. 亜鉛欠乏と免疫システム}

亜鉛欠乏により免疫システムの異常がヒトやマウスで 多数報告されている（1-4）。亜鉛欠乏による免疫不全の 特徵は胸腺の萎縮とそれに伴ら細胞性免疫の機能低下で 
ある。亜鉛欠乏は腸性肢端皮膚炎のような遺伝性欠乏症 ばかりでなく, 種々の栄養状態（低栄養, 高カロリ一輸 液栄養時，血液透析時，薬物治療時など），生理的状態 (妊娠時，老年期), 疾病状態（慢性アルコール中毒，肺 疾患, 腸疾患, 進行癌, 鎌型赤血球症など）によっても 誘発される。実験的に亜鉛欠乏慨で飼育したマウスに招 いてはCD4 CD8 ダブルポジティブ胸腺細胞の減少を 伴った胸腺の萎縮 (5), そして末梢血リンパ球数の低下 が観察される（6）。さらにヘルパー T 細胞のサブセット に関しては Th1 細胞からの IL-2, IFN- $\gamma$ などのサイトカ イン産生の減少 (7), これらの報告と一致して, 低濃度 の亜鉛で培養したナイーブ $\mathrm{T}$ 細胞及び Th1 細胞に掞い て，マイトジェン刺激によるサイトカイン転写活性が抑 制されていた（8)。T 細胞だけではなく，ウイルス感染 細胞や腫瘍細胞の除去に重要な役割を担っているナチュ ラルキラー細胞に拈いても, 亜鉛欠乏によって, 細胞障 害活性低下などが報告されている(9)。

一方，亜鉛製剤であるポラプレジンク（商品名：プロ マック）を潰瘍性大腸炎誘発マウスに投与すると，臨床 症状が改善されることが報告されている $(10,11)$ 。この 結果と一致して亜鉛投与マウスでは炎症組織での好中球 浸潤，炎症性サイトカインの産生が抑制されていた。こ れらの報告より亜鉛が免疫システムに作用して, 炎症疾 患を抑制することが示唆された。

このように免疫システムに打ける亜鉛の重要性が指摘 されていたにもかかわらず，どのようなメカニズムで， 亜鉛が免疫システムを制御しているか十分には提示され ていなかった。次項より，著者の研究グループが報告し てきた研究成果を中心に，胸腺萎縮を含む細胞性免疫シ ステムに打ける亜鉛の役割については項目 3, アレル ギ一応答に打ける亜鉛の役割については項目 4, 自己免 疫疾患と亜鉛の関連については項目 5 に拈いてそれぞれ 解説する。

\section{3. 亜鉛による細胞性免疫システムの制御}

\section{3-1．亜鉛欠乏による胸腺萎縮の分子機構}

胸腺は二次リンパ器官の一つで，ナイーブ $\mathrm{T}$ 細胞が自 己及び非自己の識別を獲得するための必須の組織であ る。先に述べたように, 亜鉛欠之によって, 胸腺の萎縮 が観察される。この萎縮には亜鉛欠乏によって, 副腎皮 質からの分泌が充進される血中のグルココルチコイドが 関わっている可能性が示唆されている。事実, グルココ ルチコイドの分泌充進を抑制するために, 副腎摘出手術 を施したマウスでは亜鉛欠乏による胸腺萎縮が軽減され た（12）。また，グルココルチコイドは胸腺のナイーブ T 細胞にアポトーシスを誘導する (5)。現時点で, 亜鉛欠 そによって分泌充進したグルココルチコイドによって胸 腺のナイーブ $\mathrm{T}$ 細胞が減少することで, 胸腺萎縮が観察 された可能性が考えられた。

\section{3-2.．亜鉛による T 細胞機能制御}

亜鉛欠乏によって T 細胞の機能異常を呈することが知 られている。 $\mathrm{T}$ 細胞は抗原を認識する抗原受容体を発現 して打り，この抗原受容体の活性化には補助受容体と呼 ばれる CD4 やCD8 と恒常的に会合しているチロシンキ ナーゼ lymphocyte-specific protein tyrosine kinase (Lck) の 活性化が必要である。Kim らは補助受容体と Lck の会合 に亜鉛が必須であることを構造解析により示した（13）。 これらの報告より，亜鉛欠乏によって補助受容体と Lck の会合に影響を及ぼし， T 細胞機能異常を呈する可能性 が考えられた。

\section{3-3. 亜鉛による樹状細胞成熟化機構の制御}

樹状細胞は病原体などの外来性抗原を取り込み, 細胞 内で分解を行った後，MHCクラスII分子を介して，その 外来性抗原ぺプチドをナイーブ $\mathrm{T}$ 細胞に抗原提示する細 胞性免疫において重要な役割を担う。また，樹状細胞は 抗原を捕捉後, 細菌の菌体成分である Lipopolysaccharide （LPS）の刺激を受け取って, 細胞表面の MHC クラス II 分子の発現を高め, 成熟樹状細胞に分化誘導される。

著者の研究グループに打いて, 樹状細胞をLPS で刺激 した後，亜鉛蛍光プローブを用いて細胞内の亜鉛濃度を 観測したところ, 亜鉛が樹状細胞の成熟に伴って減少し， 同時に獲得免疫反応に重要な MHC クラス II の細胞表面 に打ける発現レベルが上昇していることを見出した (14)。続いて，樹状細胞成熟化に打严鉛濃度の影響 を調べるために, 亜鉛キレート剂である TPEN $\left(N, N, N^{\prime}, N^{\prime}\right.$ Tetrakis (2-pyridylmethyl) ethylenediamine) を用いて細胞内 亜鉛をキレートしたところ，樹状細胞表面の MHC クラ ス II の発現増加が認められた。さらに詳細に樹状細胞内 の MHC クラス II の局在を検討してみたところ, TPEN 処 理した樹状細胞では LPS 処理した樹状細胞と同様に細 胞膜に MHC クラス II の発現が認められるが, 大部分の MHC クラス II はエンドソーム分画に残存していること がわかった。このことから, 細胞内亜鉛のキレートによっ て観察された細胞膜での MHC クラス I蓄積は, エン ドソーム分画の MHC クラス IIが積極的に細胞膜へ輸送 されたのではなく, 定常状態で活発に起こっている $\mathrm{MHC}$ クラス Iのエンドサイトーシス，すなわち細胞膜からエ ンドソームへの移動を抑制している可能性が推察され た。事実, 無刺激, LPS 刺激, TPEN 処理した樹状細胞 に打ける細胞膜の MHC クラス I発現レベルを追ったと ころ，TPEN 処理樹状細胞と LPS 刺激樹状細胞は，いず れも MHCクラス IIエンドサイトーシスが抑制されて いた。これらの結果はLPS 刺激時のエンドサイトーシス の抑制に亜鉛要求性の機構が存在している可能性を示唆 している。亜鉛イオノフォアを用いて亜鉛を細胞内に強 制導入し，LPS 刺激を加えた場合には，細胞膜 MHC ク ラスПの発現レベルの増加が見られず，亜鉛キレーター 処理と逆の効果が観察された。以上のことより，LPS 刺 激による樹状細胞の成熟過程に, 細胞内亜鉛濃度の低下 


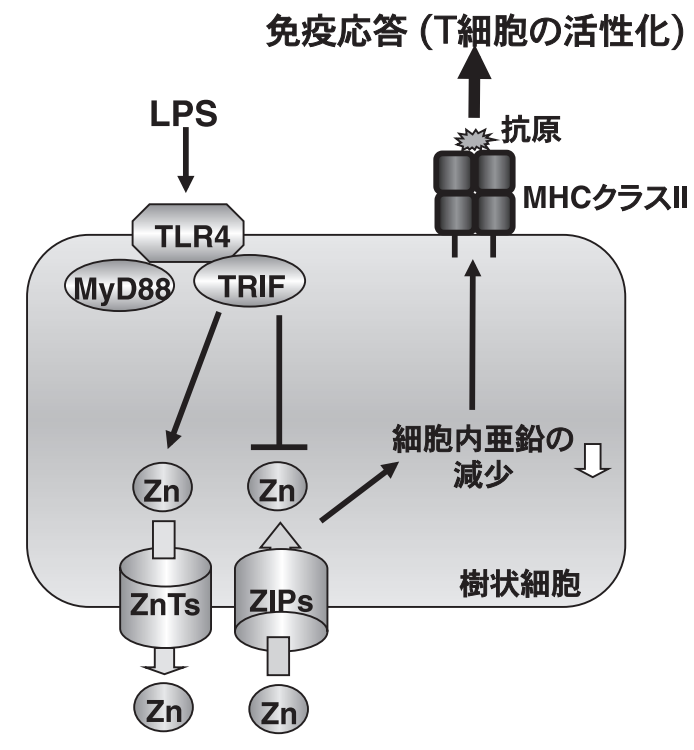

図 1 樹状細胞の成熟・活性化における亜鉛の役割。細菌の細 胞壁成分であるLPS によるシグナルが亜鉛トランスポーターの 発現依存的に細胞内亜鉛濃度を低下させて扣り, この細胞内亜 鉛が低下することが細胞表面に打ける MHC クラス II 発現など の樹状細胞の成熟・活性化に必須であることが明らかになった。 このことは，亜鉛トランスポーターの転写依存的な細胞内亜鉛 濃度のダイナミックな変化が, 細胞成熟に抢けるシグナルとし て機能していることを示唆している。

が必要であることが示唆された。

細胞内亜鉛レベルの制御には亜鉛トランスポーターが 必要である。LPS 刺激した樹状細胞の亜鉛トランスポー ターの mRNA 発現レベルのプロファイリングを行った ところ, 図 1 に示した TRIF 経路依存的に亜鉛を細胞質内 に取り込む亜鉛インポーター（ZIP6）が減少し，それと は対照的に亜鉛を細胞質から細胞外へ排出する亜鉛エク スポーター (ZnT1) が増加していることがわかった。し たがって, LPS 刺激による細胞内亜鉛濃度の減少は, 亜 鉛トランスポーターの発現に起因するものと推察され た。実際に細胞膜に発現し, 細胞外から細胞内への亜鉛 輸送を制御しているZIP6（ZIP6 の詳細は本シリーズ「リ フレッシュが必要な微量元素に関する常識」神戸氏の解 説を参照 (15)）を強制発現させた樹状細胞を LPS で刺激 すると, 細胞膜の MHC クラス II 発現の増加は抑制され た。樹状細胞の MHC クラス II は CD4 陽性 T 細胞の活性 化に必須である。よって, 樹状細胞と共培養した CD4 陽 性 T 細胞活性化による IL-2 産生量の減弱を導いた。この ことは亜鉛が樹状細胞に拈いて MHC クラス II の発現制 御に関与し, $\mathrm{T}$ 細胞を介した免疫応答を調節しらること を意味している。すなわち，亜鉛トランスポーターによ る細胞内亜鉛レベルの減少が樹状細胞の成熟機序に関与 しており，樹状細胞を介する細胞性免疫の制御に関与し ていることが明らかとなった。（図 1)。上述してきたよ らに，亜鉛トランスポーターが細胞内亜鉛濃度を変化さ せることによって，細胞性免疫に重要な役割を担ってい る樹状細胞の分化に影響を及ぼしていることを示すこと
ができたが, MHCクラス II の細胞内のトラフィッキング に亜鉛濃度変化がどらいった分子を介して制御を担って いるかに関しては今後の課題である。

\section{4. 亜鉛とマスト細胞及びアレルギー反応の制御}

マスト細胞はアレルギー反応で役割を果たしている骨 髄由来の顆粒細胞である（16-18）。マスト細胞は，ヒス タミンなどの化学伝達物質を貯蔵した顆粒を有して抒 り，さらにその顆粒中には亜鉛が蓄積していることが明 らかになっている $(19,20)$ 。しかしながら，顆粒中の亜 鉛の役割やマスト細胞の活性化に拈ける亜鉛の重要性に ついては明らかになっていなかった。

筆者の研究グループでは, マスト細胞の活性化におけ る亜鉛の役割を検討する目的で覀鉛のキレート剂 TPEN をマウスに投与した。その結果，血管透過性を指標とし た局所性アナフィラキシ一反応が TPEN の投与量依存的 に抑制されることが確認された（21）。このときの耳の組 織切片に打けるマスト細胞の形態から，TPEN投与を 行った個体では脱顆粒反応が低下していることが明らか になった。またTPEN は全身性アナフィラキシー反応に 対して子抑制効果を示すことが確認された。さらに骨髄 由来のマスト細胞を用いてマスト細胞活性化に対する TPEN の阻害効果を検討した結果, TPEN 処理により脱顆 粒反応，ロイコトリエン産生，扎よび IL-6 と TNF $\alpha$ など のサイトカイン産生が低下していた。TPEN は亜鉛以外 の銅，鉄，拈よびマンガンに対してもある程度のキレー 卜効果があるが，銅，鉄，マンガンのキレート剤はマス 卜細胞の活性化を抑制しなかったことから，抗原刺激依 存的なマスト細胞の活性化に亜鉛が関与していることが 示唆された。TPEN は抗原受容体の下流の Syk, LAT, お よびPLC 22 のリン酸化やカルシウムシグナルに対する 阻害効果を示さなかったが，脱顆粒反応に重要なプロセ スである細胞内顆粒の細胞膜への移動（顆粒移動）を抑 制することが明らかになった。最近，マスト細胞の顆粒 移動を調節する分子として低分子量 $\mathrm{G}$ タンパク質の一 員であるARF1（ADP-Ribosylation Factor1）の同定に成功 した $(22,23)$ 。さらに，この ARF1 の活性化は TPEN で阻 害されることが判明し，TPEN 処理による脱顆粒反応抑 制の標的分子として, ARF1 が考兄られた。一方，マス 卜細胞を抗原刺激した際のサイトカイン産生に対する TPEN の阻害機構を検討した結果, IL-6 と TNF $\alpha$ の主要 な転写調節因子である NF- $\mathrm{KB}$ の抗原刺激依存的な核移 行が TPEN 処理により大幅に抑制されており，その上流 の IKB のリン酸化とユビキチン化による分解, そして IKK の活性化が低下していることが判明した。さらに PKC $\beta 1$ の活性化に重要な細胞膜への移行が TPEN処理に より阻害されていたことから, PKC $\beta 1-N F-\kappa B$ 経路を介し た炎症性サイトカインの産生に亜鉛が関与していること が明らかになった。また，著者らの研究グループではマ スト細胞で高発現していた細胞質からゴルジ体及び小胞 


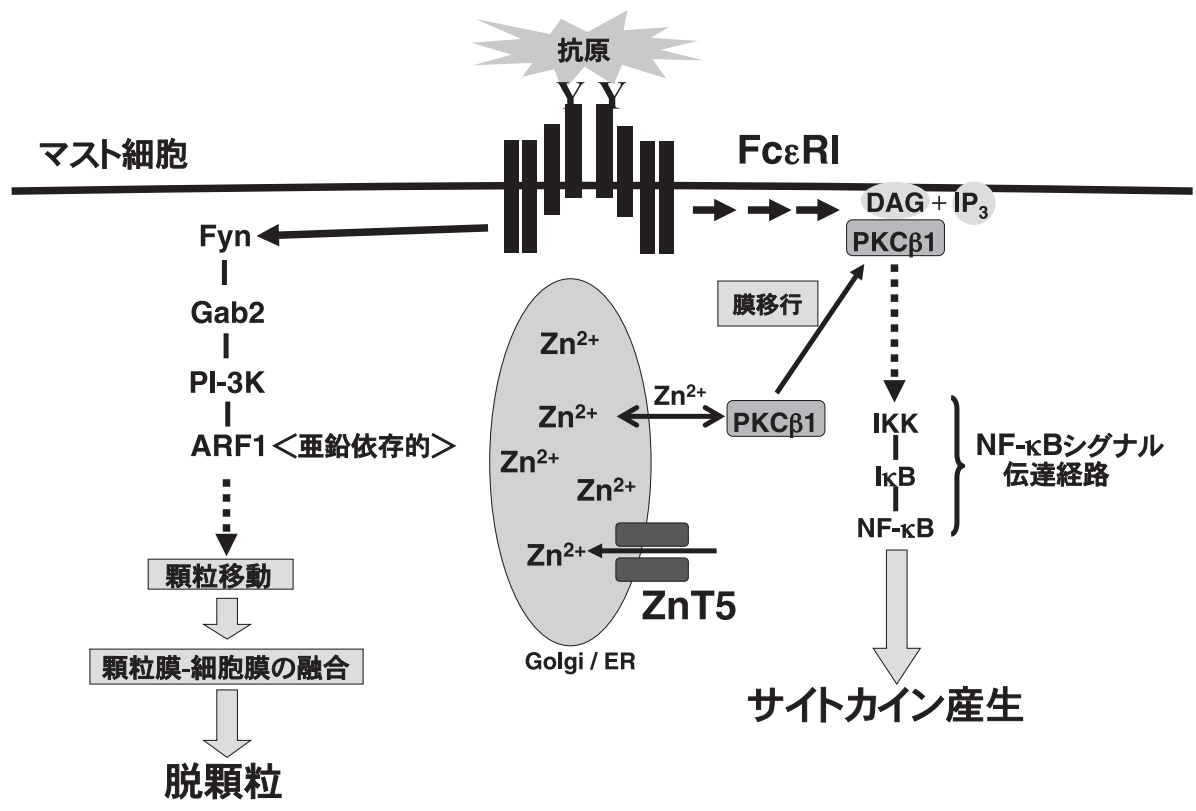

図 2 マスト細胞における亜鉛／亜鉛トランスポーターの役割。マスト細胞の活性化に亜鉛が関与している。ヒスタミン遊離を伴う 脱顆粒に関して，細胞質内のヒスタミン含有顆粒が細胞膜へ移行するステップが必要であることが示されている(顆粒移動)。亜鉛は この顆粒移動の調節を担っている ARF1 分子の活性化を制御している。また，PKC 依存的なサイトカイン産生に関しては，PKCが亜 鉛結合蛋白であり，PKC に亜鉛が供給されなくなると，活性化に重要なステップである PKC の膜移行が障害される。亜鉛トランス ポーターZnT5 は細胞質内のゴルジ体（Golgi）や小胞体（endoplasmic reticulum: ER）への亜鉛を供給する輸送体で，これらのオルガ ネラからのPKCへの亜鉛供給が恒常的に存在しているものと考光ている。

体への亜鉛輸送に関わっている亜鉛トランスポーター ZnT5（ZnT5 の詳細は本シリーズ「リフレッシュが必要 な微量元素に関する常識」神戸氏の解説を参照 (15)）に 着目した。ZnT5 遺伝子欠損マウス由来のマスト細胞では 抗原刺激依存的な PKC $\beta 1$ の膜移行及び, それにともなら サイトカイン産生が障害されていた (24)。マスト細胞活 性化に打ける亜鉛の作用点に関して図 2 に模式化した $(25,26)$ 。脱顆粒に関してはARF1 分子依存的な細胞内顆 粒移動, サイトカイン産生に関してはPKCの膜移行のプ ロセスを抑制していると考えている（図2）。

上述してきた一連の実験によって, 亜鉛がマスト細胞 の活性化に重要な役割を担っていることが示されたが, 顆粒内に蓄積されている亜鉛の意義は未だ, 十分に理解 されていない。今後は顆粒亜鉛の免疫システムでの役割 を明らかにする必要性がある。

\section{T細胞依存性の自己免疫疾患における亜鉛の役割}

亜鉛供給によって，マウスに打いて自己免疫疾患発症 を抑える報告がなされている $(10,11)$ 。自己免疫疾患の 発症には T 細胞が重要な役割を担っていることから, 亜 鉛と $\mathrm{T}$ 細胞の活性化になんらかの関係があることが示唆 されたが，これまで， T 細胞機能発現における亜鉛の役 割に関しては十分には理解されていなかった。

$\mathrm{CD} 4$ 陽性 T 細胞はそのサイトカイン産生パターンの違 いから Th1，Th2，Th17 細胞サブセットに分類されてお り，それぞれの細胞の免疫反応に打ける役割も示されて
いる。特に，IL-17 を産生する Th17 細胞は慢性炎症性疾 患であるコラーゲン誘導性の関節炎 (collagen-induced arthritis: CIA) や実験的自己免疫性脳脊髄炎 (experimental autoimmune encephalomyelitis: EAE）の発症に寄与してい ることが IL-17 遺伝子欠損マウスの解析から明らかと なっている(27-29)。また，ナィーブ T 細胞から Th17 細 胞への分化誘導にはサイトカインである TGF- $\beta$ と IL-6 の刺激が必要である(30-32)。

北林らは亜鉛を飲料水に加えて，マウスに与えること によって亜鉛と自己免疫疾患の関係について調べた (33)。興味深いことに亜鉛を供給したマウスに扣いて, コラーゲン誘導性の関節炎や実験的自己免疫性脳脊髄炎 を誘導させても，通常水を摂取したマウスに比べ，病態 の重症化が軽減されることが判明した。さらに, 亜鉛水 を摂取させたマウスに EAE を誘導後, Th17 細胞を調整 し, 正常マウスへ移植を実施し, 病態の発症過程を観察 したところ，コントロールマウス由来の Th17 細胞を同 じ数だけ移植したマウスと同程度であったことから, Th17 細胞の機能発現に亜鉛が関与している可能性は否 定された。

そこで，IL-6によるTh17 細胞の分化誘導に関して, in vitroの解析を行った結果，亜鉛処理によって，IL-6 誘導 性の Th17 細胞への分化誘導が障害されることを見出し た。さらに，亜鉛処理による Th17 細胞分化への分子機 序を調べる目的で, IL-6 刺激で活性化されるシグナル分 子, STAT3の活性化について検討を行った。亜鉛添加に よって, IL-6 刺激後の Th17 細胞に打ける STAT3 のリン 
亜鉛無添加

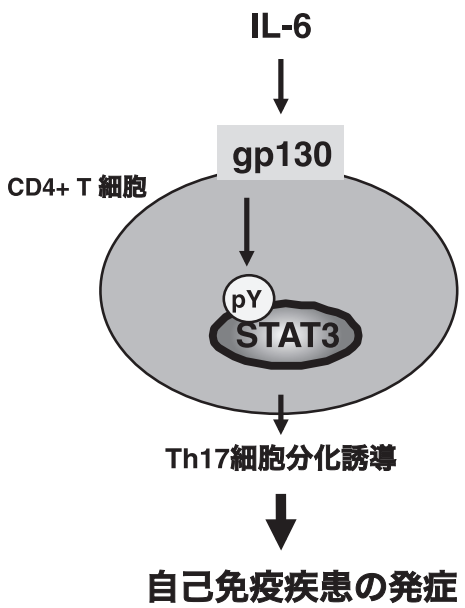

垔鉛添加

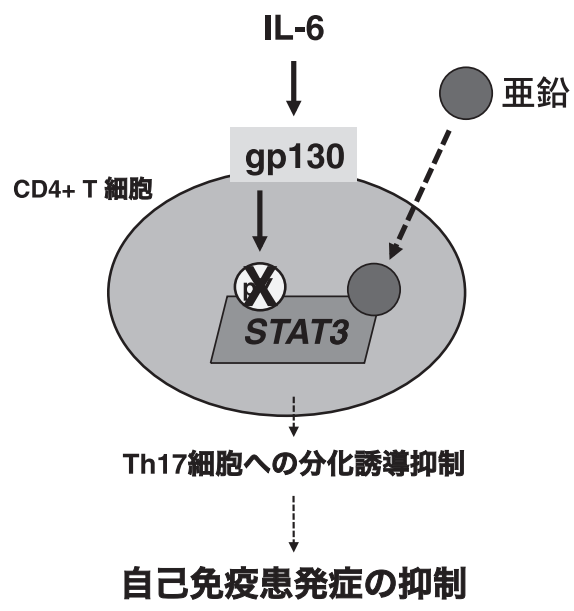

図 3 亜鉛はIL-6/STAT3 シグナル伝達経路を抑制することにより炎症性疾患の発症を抑制している。亜鉛は転写因子 STAT3 に直接 作用することにより，構造変化を引き起こす。その結果，IL-6 の刺激を受けてもSTAT3 はリン酸化されない。亜鉛による自己免疫疾 患抑制機構として，これら IL-6 依存性のTh17 細胞への分化障害を明らかとした。

酸化レベルは減弱しており，このことにより亜鉛が Th17 細胞への分化誘導を抑制することが，初めて明らかと なった。亜鉛によるSTAT3 のリン酸化抑制は亜鉛が, STAT3 に直接, 結合することでSTAT3のリン酸化キナー ゼJAKによるリン酸化を障害していることが推察され た。この結果と一致して，亜鉛水を摂取させたマウスに おいて, リンパ節の Th17 細胞数が低下していることが 観察された（図 3)。以上の結果より，従来から観察され ていた亜鉛補充による慢性自己免疫疾患に対する抑制効 果は, 近年, 炎症疾患発症に関与することが指摘されて いるサイトカイン IL-17 の産生細胞である Th17 細胞の分 化抑制によるものである可能性が示唆された。今後は亜 鉛が STAT3 に結合することで, ぞのようにして STAT3 のリン酸化を抑制しているのか詳細を解析していく予定 である。

\section{6. 亜鉛シグナルと免疫反応}

近年, 細胞内金属イオンを可視化する蛍光プローブの 開発に伴い, ごく微量の細胞内亜鉛イオンの存在が明ら かになり, 生体内総亜鉛量の恒常性に加えて, 細胞応答 に拈ける細胞内亜鉛イオンの重要性が明らかになってき た。神経細胞に扔いては，シナプス小胞に貯蔵されてい る亜鉛が生理的刺激に応答して細胞外に放出され，この 亜鉛がイオンチャネルの機能調節や細胞死誘導に関与し て抒り，亜鉛自身が神経伝達物質として働くことが明ら かになっている(34-36)。このことは, 亜鉛が細胞間情 報伝達を行らシグナル分子としての役割を果たしている ことを示唆している。しかし，免疫担当細胞の活性化に 伴って亜鉛イオンがどのような動態をしめすのか不明で あった。
著者は，このアレルギ一応答時に主要な役割を果たす マスト細胞に扮いて，抗原刺激依後，2３分程度で細 胞内亜鉛の増加が検出でき, 約 15 分後に亜鉛濃度がピー クに到達する「亜鉛ウェーブ」の存在を明らかにした (37)。亜鉛ウェーブで見られる細胞内亜鉛イオンの一過 的上昇は，細胞外から細胞質への亜鉛の流入ではなく核 周辺の小胞体近傍から発生していることがわかった。マ スト細胞は活性化に伴って即時型の脱顆粒反応と炎症性 サイトカインの転写を介した遅延型の炎症反応を惹起す ることが知られて扣り，この亜鉛ウェーブはサイトカイ ン産生に関わるシグナル伝達を増強させることが示され た。このことは, カルシウムイオンと同様に亜鉛イオン が細胞内シグナル伝達を調節するセカンドメッセン ジャーとして機能することを示唆している。また，この 亜鉛ウェーブの制御には Syk P PLC $\gamma$ を介したカルシウ ムシグナル伝達経路が関与しているが，イオノフォアを 用いた一過的なカルシウム濃度の上昇だけでは亜鉛 ウェーブは誘起されず，カルシウム濃度上昇と並行して MAP キナーゼの活性化も必要であることが見出された。 最近，著者は，マスト細胞の小胞体において亜鉛透過性 の L 型カルシウムチャネル (LTCC) のサブュニット $\alpha_{1 D}$ が発現しており，抗原刺激依存的な亜鉛ウェーブを制御 していることを見出した（38）。LTCCのアンタゴニスト であるベラパミル (Verapamil) でマスト細胞を処理する と，抗原刺激依存的な亜鉛ウェーブは抑制された。一方 で，チャネルのアゴニストである BayK8644の単独刺激 が亜鉛の上昇を誘導し，この亜鉛の上昇はVerapamil の 前処理により消失し，カルシウム非含有反応液中でも見 られた。これらの結果は, LTCC が直接亜鉛ウェーブの 制御に関与していることを示唆していた。事実， $\alpha_{1 \mathrm{D}}$ サ ブュニットをノックダウンしたマスト細胞では，抗原刺 


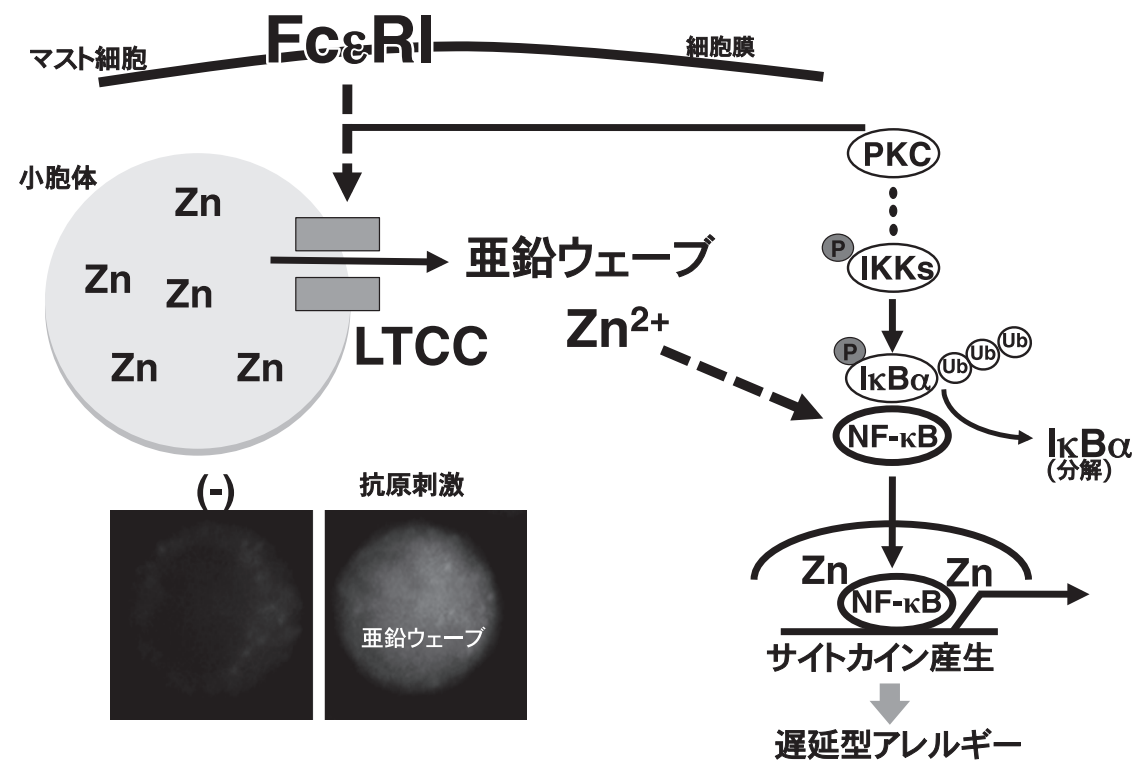

図 4 細胞内セカンドメッセンジャーとしての亜鉛。マスト細胞内遊離亜鉛が抗原刺激後に上昇していることが観察された。この現 象を亜鉛ウェーブと呼ぶ。下段の写真; 亜鉛検出プローブの Newport Green で細胞内亜鉛動態を蛍光顕微鏡にて観察。小胞体から亜 鉛が亜鉛透過性イオンチャネルLTCCを介して，細胞内に放出されていることが示された。細胞内に発生した亜鉛ウェーブはサイト カイン転写に関与している NF-kBの活性化を制御することによって，マスト細胞におけるサイトカイン産生をポジティブに調節して いる。細胞外刺激依存的に細胞内遊離亜鉛濃度が上昇するしサイトカイン産生のシグナル伝達経路の調節を行っていることから，亜 鉛は細胞内セカンドメッセンジャーとして働いていることが示唆された。

激依存的な亜鉛ウェーブが抑制され, Verapamil 処理細胞 抢よび $\alpha_{1 \mathrm{D}}$ ノックダウン細胞に拈いて抗原刺激依存的な サイトカイン産生の低下が確認できた。

さらに，著者は亜鉛ウェーブの標的分子の同定を試み

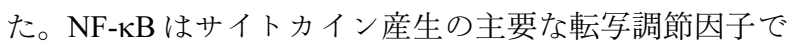
あり，Verapamil を処理した細胞では NF-кB のターゲッ トDNAへの結合能が減少しており，亜鉛を添加すると DNA 結合能抢よびサイトカイン産生能は回復した。ま た，マスト細胞依存的な炎症反応マウスモデルを用いて 生体での亜鉛ウェーブの重要性を検討したところ, Verapamil を予め耳に塗布したマウスでは炎症反応が抑 制されることが明らかになった。これらの結果から，マ スト細胞に扣いて抗原刺激依存的な亜鉛ウェーブは, LTCC 依存的に起こり, 小胞体から放出された亜鉛が NF$\kappa \mathrm{B} の \mathrm{DNA}$ 結合能を増強させることによって炎症性サイ トカインの産生調節の亜鉛シグナルとして機能している ことが明らかになった（図4）。

マスト細胞で見られた亜鉛ウェーブと同様の刺激依存 的な細胞内亜鉛イオン濃度の上昇と亜鉛の細胞活性化に おける役割については, 単球, 好中球, $\mathrm{T}$ 細胞, $\mathrm{B}$ 細胞 に打いても報告されている（39-42）。な拈， T 細胞に扮 ける刺激依存的な細胞内亜鉛イオンの上昇は, 細胞膜に 局在しているZIP6 を介した細胞外からの亜鉛イオンの 流入が必要であり，この点はマスト細胞で見られる亜鉛 ウェーブと異なっている（41）。今後，亜鉛シグナルに抒 ける免疫システムの重要性がさらに明白になることが期 待される。

\section{7. おわりに}

免疫システムに招いて，免疫担当細胞の分化・機能発 現に亜鉛が深く関わっていることが示されつつある。こ れらの研究成果は亜鉛キレート剂や，細胞内の亜鉛恒常 性維持を司っている亜鉛トランスポーターなどの亜鉛関 連遺伝子の発現を人為的に操作することにより証明され ている。我々が通常生活していくらえではこのような状 況は起こりえない。しかしながら, 冒頭で述べたように, 生体内で合成できない微量必須元素の亜鉛は，栄養を摂 取するための食事, または様々な病気を治療するための 薬剤の服用といった我々の生活環境の変化のなかで，亜 鉛欠乏状態に陥るケースが想像される。また，老化にと もなって生体内の亜鉛量が減少していくことが報告され て扣り (43, 44-46), 日本が抱える超高齢化社会を考慮し て，今後も亜鉛欠乏と免疫システムの関係を追求してい くことは重要な課題であると考えている。

一方，下痢症が小児の大きな死因の一つになっている アフリカを含む発展途上国では，小児において亜鉛補充 療法が明らかな効果を示して扣り $(47,48)$, 下痢の期間 や重症度を軽減することができ，WHOとユニセフによ り推奨されている。亜鉛補充療法の腸管免疫システムへ の影響に関しては今後の解析が必要であるが，これらの 臨床的知見は亜鉛が感染症の治療・予防に効果的である ということを示している。

著者の研究グループでは栄養素としての亜鉛研究か ら，亜鉛ウェーブの研究成果で示したように，積極的に 亜鉛が免疫系の恒常性維持に関わっていることを示しつ 
つある（49-53）。環境的素因のひとつとして亜鉛に着目 することによって，免疫システムの仕組みを理解するた めのアプローチの糸ロが見えてきた。

\section{利益相反なし}

\section{文献}

( 1 ) Frost P, Chen JC, Rabbani I, Smith J, Prasad AS. The effect of zinc deficiency on the immune response. Prog Clin Biol Res 1977;14:143-153.

( 2 ) Fraker PJ, Jardieu P, Cook J. Zinc deficiency and immune function. Arch Dermatol 1987;123:1699-1701.

( 3 ) Keen CL, Gershwin ME. Zinc deficiency and immune function. Annu Rev Nutr 1990;10:415-431.

(4) Prasad AS. Zinc in human health: effect of zinc on immune cells. Mol Med 2008;14:353-357.

( 5 ) King LE, Osati-Ashtiani F, Fraker PJ. Apoptosis plays a distinct role in the loss of precursor lymphocytes during zinc deficiency in mice. J Nutr 2002;132:974-979.

(6) King LE, Frentzel JW, Mann JJ, Fraker PJ. Chronic zinc deficiency in mice disrupted $\mathrm{T}$ cell lymphopoiesis and erythropoiesis while B cell lymphopoiesis and myelopoiesis were maintained. J Am Coll Nutr 2005;24:494-502.

( 7 ) Prasad AS. Effects of zinc deficiency on Th1 and Th2 cytokine shifts. J Infect Dis 2000;182 Suppl 1:S62-68.

( 8 ) Bao B, Prasad AS, Beck FW, Godmere M. Zinc modulates mRNA levels of cytokines. Am J Physiol Endocrinol Metab 2003;285:E1095-1102.

( 9 ) Allen JI, Perri RT, McClain CJ, Kay NE. Alterations in human natural killer cell activity and monocyte cytotoxicity induced by zinc deficiency. J Lab Clin Med 1983;102:577589.

(10) Ohkawara T, Takeda H, Kato K, Miyashita K, Kato M, Iwanaga T, Asaka M. Polaprezinc (N-(3-aminopropionyl)L-histidinato zinc) ameliorates dextran sulfate sodiuminduced colitis in mice. Scand J Gastroenterol 2005;40: 1321-1327.

(11) Tran CD, Ball JM, Sundar S, Coyle P, Howarth GS. The role of zinc and metallothionein in the dextran sulfate sodium-induced colitis mouse model. Dig Dis Sci 2007; 52:2113-2121.

(12) DePasquale-Jardieu P, Fraker PJ. Further characterization of the role of corticosterone in the loss of humoral immunity in zinc-deficient $\mathrm{A} / \mathrm{J}$ mice as determined by adrenalectomy. J Immunol 1980;124:2650-2655.

(13) Kim PW, Sun ZY, Blacklow SC, Wagner G, Eck MJ. A zinc clasp structure tethers Lck to T cell coreceptors CD4 and CD8. Science 2003;301:1725-1728.

(14) Kitamura H, Morikawa H, Kamon H, Iguchi M, Hojyo S, Fukada T, Yamashita S, Kaisho T, Akira S, Murakami M, Hirano T. Toll-like receptor-mediated regulation of zinc homeostasis influences dendritic cell function. Nat Immunol 2006;7:971-977.

(15) Kambe T. Overview of and update on the physiological functions of Mammalian zinc transporters. Nihon Eiseigaku
Zasshi 2013;68:92-102.

(16) Galli SJ, Tsai M, Piliponsky AM. The development of allergic inflammation. Nature 2008;454:445-454.

(17) Kawakami T, Ando T, Kimura M, Wilson BS, Kawakami Y. Mast cells in atopic dermatitis. Curr Opin Immunol 2009;21:666-678.

(18) Voehringer D. Protective and pathological roles of mast cells and basophils. Nat Rev Immunol 2013;13:362-375.

(19) Gustafson GT. Heavy metals in rat mast cell granules. Lab Invest 1967;17:588-598.

(20) Ho LH, Ruffin RE, Murgia C, Li L, Krilis SA, Zalewski PD. Labile zinc and zinc transporter ZnT4 in mast cell granules: role in regulation of caspase activation and NFkappaB translocation. J Immunol 2004;172:7750-7760.

(21) Kabu K, Yamasaki S, Kamimura D, Ito Y, Hasegawa A, Sato E, Kitamura H, Nishida K, Hirano T. Zinc is required for FcepsilonRI-mediated mast cell activation. J Immunol 2006;177:1296-1305.

(22) Nishida K, Yamasaki S, Hasegawa A, Iwamatsu A, Koseki $\mathrm{H}$, Hirano T. Gab2, via PI-3K, regulates ARF1 in FcepsilonRI-mediated granule translocation and mast cell degranulation. J Immunol 2011;187:932-941.

(23) Nishida K. [Role of adaptor molecule Gab2 in mast cellmediated allergy response]. Yakugaku Zasshi 2013;133: 413-418.

(24) Nishida K, Hasegawa A, Nakae S, Oboki K, Saito H, Yamasaki S, Hirano T. Zinc transporter Znt5/Slc30a5 is required for the mast cell-mediated delayed-type allergic reaction but not the immediate-type reaction. J Exp Med 2009;206:1351-1364.

(25) Nishida K, Hirano T. [Role of zinc/zinc transporter in allergic response]. Seikagaku 2010;82:814-824.

(26) Nishida K. [Role of zinc transporter in allergic reactions] Yakugaku Zasshi 2011;131:85-92.

(27) Afzali B, Lombardi G, Lechler RI, Lord GM. The role of T helper 17 (Th17) and regulatory $\mathrm{T}$ cells (Treg) in human organ transplantation and autoimmune disease. Clin Exp Immunol 2007;148:32-46.

(28) Iwakura $Y$, Ishigame H. The IL-23/IL-17 axis in inflammation. J Clin Invest 2006;116:1218-1222.

(29) Hirota K, Hashimoto M, Yoshitomi H, Tanaka S, Nomura T, Yamaguchi T, Iwakura Y, Sakaguchi N, Sakaguchi S. T cell self-reactivity forms a cytokine milieu for spontaneous development of IL-17+ Th cells that cause autoimmune arthritis. J Exp Med 2007;204:41-47.

(30) Bettelli E, Oukka M, Kuchroo VK. T(H)-17 cells in the circle of immunity and autoimmunity. Nat Immunol 2007; 8:345-350.

(31) Nishihara M, Ogura H, Ueda N, Tsuruoka M, Kitabayashi C, Tsuji F, Aono H, Ishihara K, Huseby E, Betz UA, Murakami M, Hirano T. IL-6-gp130-STAT3 in T cells directs the development of IL-17+ Th with a minimum effect on that of Treg in the steady state. Int Immunol 2007;19:695-702.

(32) Veldhoen M, Hocking RJ, Atkins CJ, Locksley RM, Stockinger B. TGFbeta in the context of an inflammatory cytokine milieu supports de novo differentiation of IL-17- 
producing T cells. Immunity 2006;24:179-189.

(33) Kitabayashi C, Fukada T, Kanamoto M, Ohashi W, Hojyo S, Atsumi T, Ueda N, Azuma I, Hirota H, Murakami M, Hirano T. Zinc suppresses Th17 development via inhibition of STAT3 activation. Int Immunol 2010.

(34) Xie X, Smart TG. Modulation of long-term potentiation in rat hippocampal pyramidal neurons by zinc. Pflugers Arch 1994;427:481-486.

(35) Li Y, Hough CJ, Suh SW, Sarvey JM, Frederickson CJ. Rapid translocation of $\mathrm{Zn}(2+)$ from presynaptic terminals into postsynaptic hippocampal neurons after physiological stimulation. J Neurophysiol 2001;86:2597-2604.

(36) Colvin RA, Fontaine CP, Laskowski M, Thomas D. Zn2+ transporters and $\mathrm{Zn} 2+$ homeostasis in neurons. Eur $\mathrm{J}$ Pharmacol 2003;479:171-185.

(37) Yamasaki S, Sakata-Sogawa K, Hasegawa A, Suzuki T, Kabu K, Sato E, Kurosaki T, Yamashita S, Tokunaga M, Nishida K, Hirano T. Zinc is a novel intracellular second messenger. J Cell Biol 2007;177:637-645.

(38) Yamasaki S, Hasegawa A, Hojyo S, Ohashi W, Fukada T, Nishida K, Hirano T. A novel role of the L-type calcium channel alpha1D subunit as a gatekeeper for intracellular zinc signaling: zinc wave. PLoS One 2012;7:e39654.

(39) Haase H, Hebel S, Engelhardt G, Rink L. Flow cytometric measurement of labile zinc in peripheral blood mononuclear cells. Anal Biochem 2006;352:222-230.

(40) Haase H, Ober-Blobaum JL, Engelhardt G, Hebel S, Heit A, Heine H, Rink L. Zinc signals are essential for lipopolysaccharide-induced signal transduction in monocytes. $\mathrm{J}$ Immunol 2008;181:6491-6502.

(41) Yu M, Lee WW, Tomar D, Pryshchep S, CzesnikiewiczGuzik M, Lamar DL, Li G, Singh K, Tian L, Weyand CM, Goronzy JJ. Regulation of $\mathrm{T}$ cell receptor signaling by activation-induced zinc influx. J Exp Med 2011;208:775785.

(42) Taniguchi M, Fukunaka A, Hagihara M, Watanabe K, Kamino S, Kambe T, Enomoto S, Hiromura M. Essential role of the zinc transporter ZIP9/SLC39A9 in regulating the activations of Akt and Erk in B-cell receptor signaling pathway in DT40 cells. PLoS One 2013;8:e58022.

(43) Prasad AS, Fitzgerald JT, Hess JW, Kaplan J, Pelen F, Dardenne M. Zinc deficiency in elderly patients. Nutrition
1993;9:218-224.

(44) Andriollo-Sanchez M, Hininger-Favier I, Meunier N, Toti E, Zaccaria M, Brandolini-Bunlon M, Polito A, O'Connor JM, Ferry M, Coudray C, Roussel AM. Zinc intake and status in middle-aged and older European subjects: the ZENITH study. Eur J Clin Nutr 2005;59 Suppl 2:S37-41.

(45) Mocchegiani E, Burkle A, Fulop T. Zinc and ageing (ZINCAGE Project). Exp Gerontol 2008;43:361-362.

(46) Kogirima M, Kurasawa R, Kubori S, Sarukura N, Nakamori M, Okada S, Kamioka H, Yamamoto S. Ratio of low serum zinc levels in elderly Japanese people living in the central part of Japan. Eur J Clin Nutr 2007;61:375-381.

(47) Bhutta ZA, Black RE, Brown KH, Gardner JM, Gore S, Hidayat A, Khatun F, Martorell R, Ninh NX, Penny ME, Rosado JL, Roy SK, Ruel M, Sazawal S, Shankar A. Prevention of diarrhea and pneumonia by zinc supplementation in children in developing countries: pooled analysis of randomized controlled trials. Zinc Investigators' Collaborative Group. J Pediatr 1999;135:689-697.

(48) Bhutta ZA, Bird SM, Black RE, Brown KH, Gardner JM, Hidayat A, Khatun F, Martorell R, Ninh NX, Penny ME, Rosado JL, Roy SK, Ruel M, Sazawal S, Shankar A. Therapeutic effects of oral zinc in acute and persistent diarrhea in children in developing countries: pooled analysis of randomized controlled trials. Am J Clin Nutr 2000;72:15161522.

(49) Hirano T, Murakami M, Fukada T, Nishida K, Yamasaki S, Suzuki T. Roles of zinc and zinc signaling in immunity: Zinc as an intracellular signaling molecule. Advances in Immunology, Vol 97 2008;97:149-176.

(50) Murakami M, Hirano T. Intracellular zinc homeostasis and zinc signaling. Cancer Science 2008;99:1515-1522.

(51) Fukada T, Yamasaki S, Nishida K, Murakami M, Hirano T. Zinc homeostasis and signaling in health and diseases: Zinc signaling. J Biol Inorg Chem 2011;16:1123-1134.

(52) Nishida K, Fukada T, Yamasaki S, Murakami M, Hirano T. Zinc in allergy, autoimmune, and hard and connective tissue diseases. In: Rink L ed. Zinc in Human Health. IOS Press, Amsterdam: 2011:268-282.

(53) Fukada T, Kambe T. Molecular and genetic features of zinc transporters in physiology and pathogenesis. Metallomics 2011;3:662-674. 